\title{
Minute Times Milligram Per Milliliter Per Milligram Per Gram Per Day
}

National Cancer Institute

\section{Source}

National Cancer Institute. Minute Times Milligram Per Milliliter Per Milligram Per Gram

Per Day. NCl Thesaurus. Code C117943.

Minute times milligram per milliliter, divided by milligram per gram per day. 